\title{
Improved large-scale hydrological modelling through the assimilation of streamflow and downscaled satellite soil moisture observations
}

\author{
Patricia López López ${ }^{1,2}$, Niko Wanders ${ }^{3}$, Jaap Schellekens ${ }^{1}$, Luigi J. Renzullo ${ }^{4}$, Edwin H. Sutanudjaja ${ }^{2}$, and \\ Marc F. P. Bierkens ${ }^{2,5}$ \\ ${ }^{1}$ Deltares, Delft, the Netherlands \\ ${ }^{2}$ Department of Physical Geography, Faculty of Geosciences, Utrecht University, Utrecht, the Netherlands \\ ${ }^{3}$ Department of Civil and Environmental Engineering, Princeton University, Princeton, New Jersey, USA \\ ${ }^{4}$ CSIRO Land and Water, Canberra, ACT, Australia \\ ${ }^{5}$ Unit Soil and Groundwater Systems, Deltares, Utrecht, the Netherlands \\ Correspondence to: Patricia López López (patricia.lopez@ deltares.nl)
}

Received: 24 September 2015 - Published in Hydrol. Earth Syst. Sci. Discuss.: 16 October 2015

Revised: 30 June 2016 - Accepted: 5 July 2016 - Published: 29 July 2016

\begin{abstract}
The coarse spatial resolution of global hydrological models (typically $>0.25^{\circ}$ ) limits their ability to resolve key water balance processes for many river basins and thus compromises their suitability for water resources management, especially when compared to locally tuned river models. A possible solution to the problem may be to drive the coarse-resolution models with locally available highspatial-resolution meteorological data as well as to assimilate ground-based and remotely sensed observations of key water cycle variables. While this would improve the resolution of the global model, the impact of prediction accuracy remains largely an open question. In this study, we investigate the impact of assimilating streamflow and satellite soil moisture observations on the accuracy of global hydrological model estimations, when driven by either coarse- or highresolution meteorological observations in the Murrumbidgee River basin in Australia.

To this end, a $0.08^{\circ}$ resolution version of the PCRGLOBWB global hydrological model is forced with downscaled global meteorological data (downscaled from $0.5^{\circ}$ to $0.08^{\circ}$ resolution) obtained from the WATCH Forcing Data methodology applied to ERA-Interim (WFDEI) and a local high-resolution, gauging-station-based gridded data set $\left(0.05^{\circ}\right)$. Downscaled satellite-derived soil moisture (downscaled from $\sim 0.5^{\circ}$ to $0.08^{\circ}$ resolution) from the remote observation system AMSR-E and streamflow observations collected from 23 gauging stations are assimilated using an en-
\end{abstract}

semble Kalman filter. Several scenarios are analysed to explore the added value of data assimilation considering both local and global meteorological data.

Results show that the assimilation of soil moisture observations results in the largest improvement of the model estimates of streamflow. The joint assimilation of both streamflow and downscaled soil moisture observations leads to further improvement in streamflow simulations (20\% reduction in RMSE).

Furthermore, results show that the added contribution of data assimilation, for both soil moisture and streamflow, is more pronounced when the global meteorological data are used to force the models. This is caused by the higher uncertainty and coarser resolution of the global forcing.

We conclude that it is possible to improve PCR-GLOBWB simulations forced by coarse-resolution meteorological data with assimilation of downscaled spaceborne soil moisture and streamflow observations. These improved model results are close to the ones from a local model forced with local meteorological data. These findings are important in light of the efforts that are currently made to move to global hyperresolution modelling and can help to advance this research. 


\section{Introduction}

In recent decades, a number of large-scale hydrological and land-surface models have been developed to quantify the global water cycle components, to analyse the human influence on the global water balance, to study climate change impact on water resources and to assess global hydrological extremes, such as drought and flood risk. VIC (Liang et al., 1994, 1996), WaterGAP (Alcamo et al., 2003), ORCHIDEE (d'Orgeval et al., 2008), HTESSEL (Balsamo et al., 2009), JULES (Best et al., 2011), PCR-GLOBWB (Van Beek et al., 2011), SURFEX-TRIP (Decharme et al., 2010, 2013) and W3RA (van Dijk, 2010; van Dijk et al., 2014) are some examples of large-scale hydrological models recently applied to provide water resources assessment over continental to global domains, but their coarse spatial resolution, typically between 0.5 and $1^{\circ}$, limits their ability to resolve key water balance processes for many river basins (Lanza et al., 1997; $\mathrm{Wu}$ and $\mathrm{Li}, 2009$ ) and thus compromises their suitability for water resources management, especially when compared to locally tuned hydrological models.

A possible solution to the problem may be to drive these original coarse-resolution models with high-resolution meteorological data. Several meteorological forcing data sets at a global scale are available, including the European Centre for Medium-Range Weather Forecasts - ECMWF ERAInterim - global atmospheric reanalysis data (Dee et al., 2011), the Climatic Research Unit Time Series - CRU TS - (Mitchell and Jones, 2005), the NASA reanalysis ModernEra Retrospective Analysis for Research and Applications MERRA - (Rienecker et al., 2011) and the WATCH Forcing Data methodology applied to ERA-Interim reanalysis data - WFDEI - (Weedon et al., 2014). They are the result of integrating Bayesian merging of the available earth observations, in situ data sets and models to construct consistent large-scale meteorological time series. Some recent scientific efforts are conducted to improve the quality and availability of these data sets, for example increasing their spatial and temporal resolution (Cannon, 2011; Ebtehaj and FoufoulaGeorgoiu, 2013; Atkinson, 2013). The use of high-spatialresolution meteorological data would indirectly improve the resolution of the large-scale model, producing higher accuracy discharge estimates. However, when models that are designed for coarse spatial resolution are used at smaller spatial scale, issues may arise with the representation of fieldscale processes. One of the major issues in this respect is the neglect of lateral flow, misleading the representation of the complex interactions between river water and groundwater (surface runoff, subsurface runoff, soil moisture state, etc.). At the moment, more research is required to understand the gain that can be obtained using these higher-spatialresolution forcing data for uncalibrated global hydrological models at finer spatial resolutions.

Another approach to bridge the gap between the different spatial scales is to assimilate ground-based and remotely sensed observations of key water cycle variables. Higherresolution satellite data contain information at finer spatial resolution and could be used to correct for suboptimal model performance at these finer resolutions. Multiple studies have used data assimilation techniques to obtain the best possible estimate of the hydrological system status, merging the strengths of hydrological modelling and observations and mitigating their respective weaknesses (Moradkhani, 2008; Clark et al., 2008; van Dijk et al., 2014). Among the sequential and variational data assimilation methods, the ensemble Kalman filter (Evensen, 2003) has arguably emerged as the most popular choice for assimilation into land surface and hydrological models. The various individual components of the water cycle, such as surface water (Vrugt et al., 2006; Rakovec et al., 2012), soil moisture (van Dijk et al., 2014; Wanders et al., 2014a), snow water (Sun et al., 2004; Moradkhani, 2008) and groundwater (Zaitchik et al., 2008; Tangdamrongsub et al., 2015), which influence the hydrological system in different ways, can be assimilated into the model.

Soil moisture assimilation has been considered to improve model estimates, due to its key role in the terrestrial water cycle and its responsibility for the partitioning of precipitation between surface water and storage through infiltration. Several studies have assimilated soil moisture data (Draper et al., 2011; Chen et al., 2011; Brocca et al., 2012; Wanders et al., 2014b; Massari et al., 2015; Alvarez-Garreton et al., 2015; Lievens et al., 2015) both based on ground soil moisture measurements and remotely sensed satellite soil moisture products from remote observation systems, such as ASCAT (Naeimi et al., 2009), SMOS (Kerr et al., 2012) and AMSR-E (Owe et al., 2008). On the other hand, surface water information has often been used for data assimilation frameworks (Vrugt et al., 2006; Rakovec et al., 2012) because discharge provides integrated information of all hydrological states, which is often very effective in improving model simulations. However, the risk of an integrated observation is that in some scenarios accurate simulations could be obtained by adjusting the wrong state's variables.

An additional improvement could be made by the assimilation of downscaled or disaggregated satellite soil moisture observations into a particular land surface model (Merlin et al., 2006; Sahoo et al., 2013). Recently, new soil moisture products of higher spatial resolution have been released (Gevaert et al., 2015) but their impact on hydrological model predictions has not yet been explored. For example, they could be used to correct for incorrectly observed (or interpolated) precipitation patterns, which directly affect the input uncertainty to the model.

Moreover, improved results can be obtained by assimilation of multiple observational data sets of different parts of the hydrological cycle into the hydrological model (Barrett and Renzullo, 2009; Reichle et al., 2014). For example, the joint assimilation of discharge and soil moisture could result in an improved understanding of the runoff generation mechanisms and increase the quality and quantity of in- 
formation incorporated to the model system. However, the added value of this type of joint assimilation procedures is largely unknown and should be further investigated (Aubert et al., 2003; Lee et al., 2011).

Many data assimilation experiments have been set up in conjunction with local-scale hydrological models and the benefit of data assimilation for large-scale models remains largely an open question. In this context, it is interesting to analyse whether the accuracy of large-scale hydrological models can be improved and become more comparable with locally calibrated model estimates if satellite observations are assimilated. Understanding the potential gain of assimilating satellite observations into large-scale models is a relevant research opportunity and may have potential benefits for water resources management (van Dijk and Renzullo, 2011). For example, in regions without or with low-quality meteorological observations, the use of large-scale models in combination with satellite data assimilation could improve our understanding of the available water resources. The primary goal of the present study is to investigate the impact of assimilating streamflow and satellite soil moisture observations on the accuracy of global hydrological model estimations, when driven by either coarse- or high-resolution meteorological observations. The Murrumbidgee River basin in the southeast of Australia was chosen as a case study for the investigation because of the variety of land uses in the area, the high level of monitoring available for a large number of relatively unimpaired catchments and the extensive body of previous studies observing and describing the hydrologic patterns across the basin (Renzullo et al., 2014; van Dijk and Renzullo, 2011). A total of eight data assimilation scenarios were considered in which discharge and soil moisture observations were either independently or jointly used, and the forcing data were obtained from either local or global data sets. In this context, comparison of the eight scenarios with the locally calibrated model estimates provides insight into how the estimations of global hydrological models driven by global forcing data can come closer to local-scale model predictions.

\section{Approach, materials and methods}

\subsection{Study basin: Murrumbidgee River, Australia}

The selected study area was the Murrumbidgee River basin $\left(84000 \mathrm{~km}^{2}\right)$ located in southeast Australia, specifically in the southwest of New South Wales (Fig. 1). The Murrumbidgee River is the second largest river in the MurrayDarling system, flowing for a distance of approximately $1600 \mathrm{~km}$. Elevations range from over $1900 \mathrm{~m}$ in the east to less than $50 \mathrm{~m}$ on the western plain. Forest and woodland coverage dominates in the east, with pasture and cropping in the central region and increasing grassland to the west. The western plain is dominated by clay-loam soils, with decreasing clay content in the middle and eastern region (Peischl et

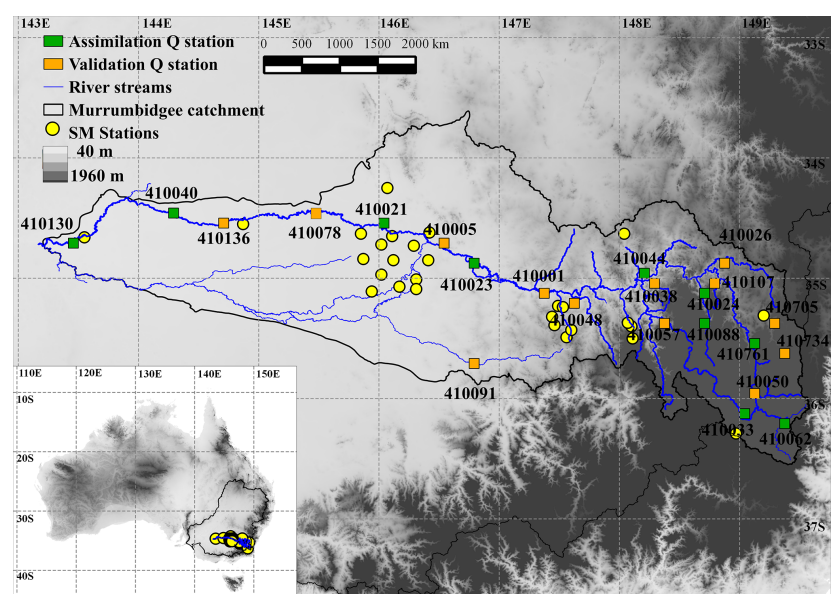

Figure 1. Map of the Murrumbidgee River basin and its location in Australia as part of the Murray-Darling system. Green squares indicate locations for assimilation of streamflow observations and orange squares indicate locations for evaluation of streamflow observations. Each streamflow location is identified with a gauging station number according to BoM (2015). Yellow points indicate locations of field-measured soil moisture observations.

al., 2012). The climate in the catchment is one of the most diverse in New South Wales, with an average annual rainfall that ranges from $1700 \mathrm{~mm} \mathrm{yr}^{-1}$, in the higher elevations of the Snowy Mountains in the east, to less than $350 \mathrm{~mm} \mathrm{yr}^{-1}$ on the western plain. Average reference evapotranspiration varies from less than $1000 \mathrm{~mm} \mathrm{yr}^{-1}$ in the southeast to over $1800 \mathrm{~mm} \mathrm{yr}^{-1}$ in the west. Mean annual flow increases from less than $45 \mathrm{~m}^{3} \mathrm{~s}^{-1}$ in the upstream tributaries to approximately $125 \mathrm{~m}^{3} \mathrm{~s}^{-1}$ in the middle Murrumbidgee (Green et al., 2011).

\subsection{Hydrological models}

The simulations for two distributed hydrological models, i.e. the local OpenStreams wflow_sbm and the global PCRGLOBWB, were performed for the period 2007-2010. The period 2000-2007 was used to spin up the models. The local and large-scale models are described in detail in the following two subsections.

\subsubsection{Local-scale model: OpenStreams wflow_sbm}

The local-scale hydrological model employed in this study was the OpenStreams wflow_sbm model (Schellekens, 2014). This is a distributed model derived from the topog_sbm simple bucket model developed by Vertessy and Elsenbeer (1999). The OpenStreams wflow_sbm model (OSWS) is programmed in the PCRaster-Python environment (Wesseling et al., 1996; Karssenberg et al., 2010) and it is publicly available through the OpenStreams project (https://github.com/openstreams/wflow). The defined spatial resolution used in this study was $0.01^{\circ} \times 0.01^{\circ}$ 


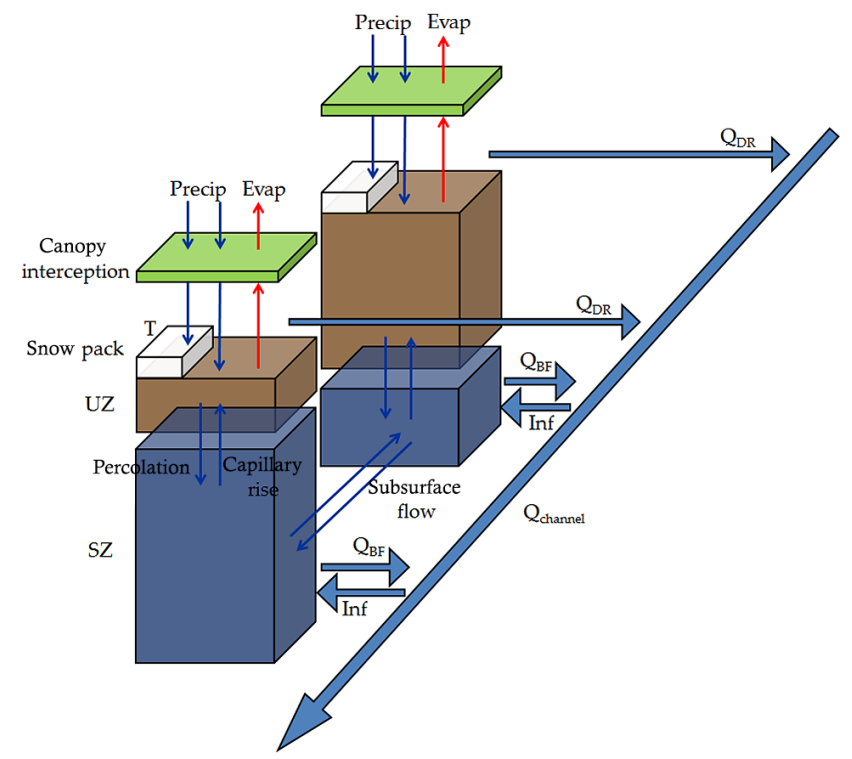

Figure 2. OpenStreams wflow_sbm model structure, adapted from Vertessy and Elsenbeer (1999) and Schellekens (2014). Symbols' definitions are as follows: Precip, precipitation; Evap, evaporation; $T$, temperature; UZ, unsaturated zone; SZ, saturated zone; Qchannel, total runoff; QDR, direct runoff; QBF, baseflow; and Inf, water flow from the river channel to the saturated zone.

$(\sim 1 \mathrm{~km} \times 1 \mathrm{~km})$ with daily temporal resolution. A schematic representation of OSWS is given in Fig. 2.

OSWS model structure consists of three main routines: (i) rainfall interception (schematized by the Gash model - Gash, 1979), (ii) soil processes (schematized by the topog_sbm model) and (iii) river drainage and overland flow (modelled by the kinematic wave routing over a drainage network).

The water enters each model cell from precipitation to the canopy interception storage or snow storage. The remaining liquid water infiltrates the soil. At the same time, water is taken from the soil through evapotranspiration (based on soil water content and vegetation type). The water exchange into the soil considers two vertical soil layers, the unsaturated zone (UZ) and the saturated zone (SZ), based on topog_sbm structure. Total runoff is the sum of the direct runoff, the melt water that does not infiltrate into the soil and the baseflow (lateral subsurface flow from the saturated zone). This total runoff is conducted along the river network as discharge with kinematic wave routing.

The OSWS model was calibrated for the Murrumbidgee River basin using observations from in situ streamflow gauges (BoM, 2015) for the time period 1990-2010. These gauges are different from those considered in all the data assimilation scenarios to ensure an independent verification.

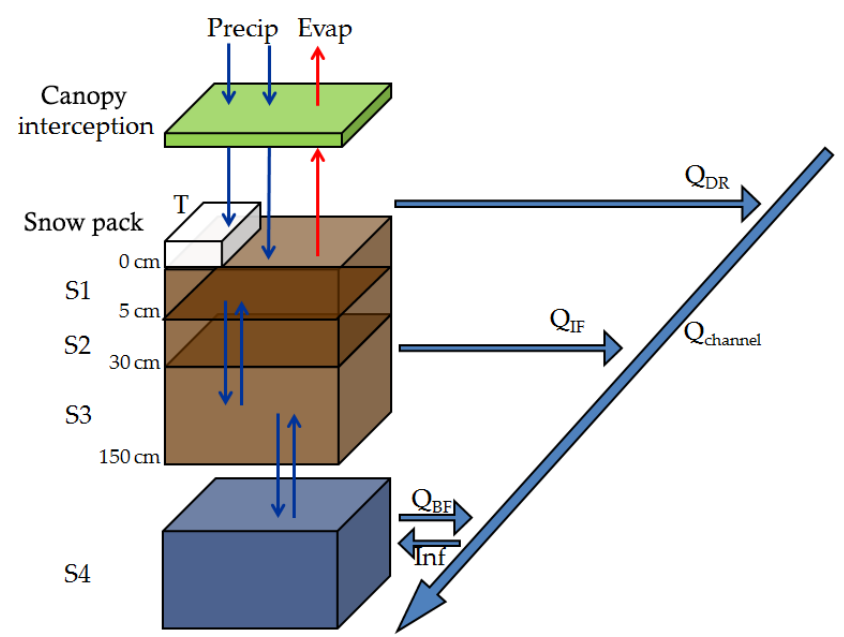

Figure 3. PCR-GLOBWB model structure, adapted from Van Beek et al. (2011). Symbols' definitions are as follows: Precip, precipitation; Evap, evaporation; $T$, temperature; S1, first soil layer; S2, second soil layer; S3, third soil layer; S4, groundwater reservoir; Qchannel, total runoff; QDR, direct runoff; QIF, intermediate flow; QBF, baseflow; and Inf, water flow from the river channel to the groundwater reservoir.

\subsubsection{Large-scale model: PCR-GLOBWB}

The large-scale hydrological model employed in this study was PCR-GLOBWB (Van Beek and Bierkens, 2009; Van Beek et al., 2011). Similar to OpenStreams wflow_sbm, PCR-GLOBWB is essentially a leaky-bucket type of model applied on a cell-by-cell basis. PCR-GLOBWB is coded in the PCRaster-Python environment. A spatial resolution of $0.08^{\circ}(\sim 10 \mathrm{~km} \times 10 \mathrm{~km}$ at the equator $)$ and a daily temporal resolution were used in this study. A schematic representation of PCR-GLOBWB is given in Fig. 3.

For each time step and cell, PCR-GLOBWB calculates the water balance components, including the water storage in three vertical soil layers $(0-5,5-30$ and $30-150 \mathrm{~cm})$ and one underlying groundwater reservoir, as well as the water exchange between the layers (percolation, capillary rise) and between the top layer and the atmosphere (rainfall, evapotranspiration and snowmelt). Subgrid variability is taken into account considering the variations of elevation, land cover, vegetation and soil. The total runoff of a cell consists of direct runoff (saturation excess surface runoff), non-infiltrating melt water, interflow (lateral drainage from the soil profile) and baseflow (groundwater runoff from the lowest linear reservoir). The simulated runoff is routed along the river network based on the Simulated Topological Networks (STN30; Vörösmarty et al., 2000). Water abstraction and consumptive water use (domestic, industrial, livestock, irrigation) and reservoir management are included.

In contrast to the local-scale model, PCR-GLOBWB was not calibrated for the study basin. Hydrological model pa- 


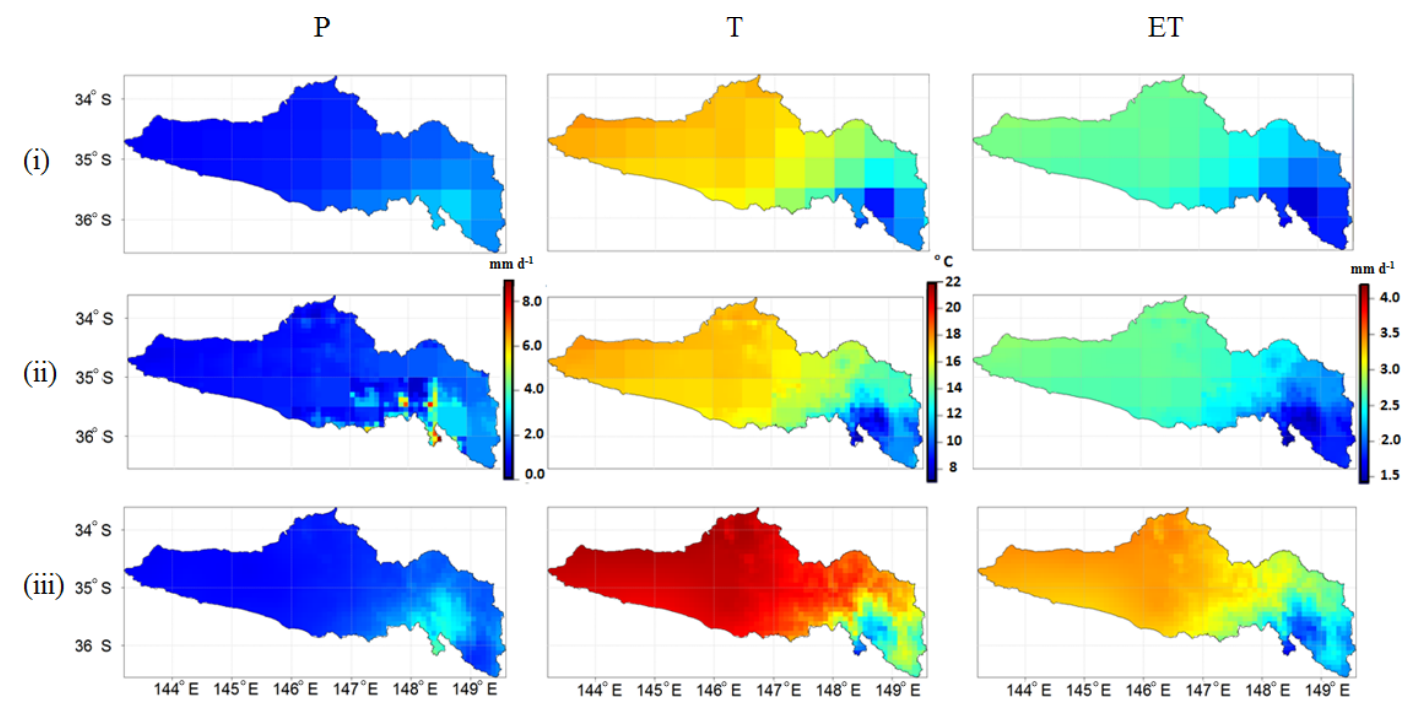

Figure 4. Daily mean precipitation, temperature and reference evapotranspiration for the time period 2007-2010 from the (i) global $\left(0.5^{\circ} \times 0.5^{\circ}\right)$, (ii) downscaled global $\left(0.08^{\circ} \times 0.08^{\circ}\right)$ and (iii) local $\left(0.05^{\circ} \times 0.05^{\circ}\right)$ forcing data sets.

rameters were derived from vegetation, soil properties or geological information and estimated at a global scale.

\subsection{Data sets}

\subsubsection{Meteorological forcing data}

The forcing data required to drive both hydrological models are precipitation and air temperature. Two types of forcing data were used in this study: local forcing data, representing the best available data, and global forcing data representing a lower spatial resolution data set but one which is available globally.

Local precipitation and air temperature data were obtained from the gridded data sets generated by the Australian $\mathrm{Bu}$ reau of Meteorology under the Australian Water Availability Project (AWAP) (Jones et al., 2009). The data are derived from station-level daily precipitation and air temperature, and interpolated on a $0.05^{\circ} \times 0.05^{\circ}$ grid covering the Australian continent. These data represent high-resolution meteorology in this study which, we argue, will provide the modelling benchmark results.

Global precipitation and air temperature data were obtained from the WATCH Forcing Data methodology applied to ERA-Interim reanalysis data - WFDEI - (Weedon et al., 2014). The daily global precipitation and air temperature data were provided at a spatial resolution of $0.5^{\circ} \times 0.5^{\circ}$. To obtain finer-spatial-resolution climate maps, from a $0.5^{\circ} \times 0.5^{\circ}$ grid to $0.08^{\circ} \times 0.08^{\circ}$ grid, a downscaling procedure was applied based on a linear regression analysis (Sutanudjaja et al., 2011). It makes use of precipitation and temperature lapse rates derived from the 10' CRU-CL2.0 climatology data set (New et al., 2002).
Local and global reference evapotranspiration (ET) were obtained through Hamon method (Allen et al., 1998; Lu et al., 2005).

Figure 4 shows the daily mean precipitation, temperature and reference evapotranspiration for the study time period (2007-2010) for both forcing data sets. Aside from the resolution difference, precipitation ranges from higher values in the mountainous regions of the catchment, with increasing variance in elevation and rainfall, to lower values in the western plain. On the contrary, temperature and, subsequently, reference evapotranspiration decrease from west to east.

Local and global forcing data show some differences in their spatial distribution and magnitude. Each climate variable shows similar spatial distribution across the various resolutions (rows in Fig. 4), with larger variations in the high elevation areas. However, local temperature magnitude differs by $3-4{ }^{\circ} \mathrm{C}$ with the global temperature, which is also reflected in the reference evapotranspiration. The downscaled global forcing data show a similar pattern to the global data with increasing resolution.

Table 1 shows the catchment daily mean values of the climate forcing variables for each year individually. Global temperature deviates from local by approximately $3-4{ }^{\circ} \mathrm{C}$, which is also reflected in reference evapotranspiration, but less pronounced. Local and global precipitation, by contrast, are very similar for each year.

\subsubsection{Soil moisture data}

Soil moisture observations retrieved from AMSR-E (Advanced Microwave Scanning Radiometer - EOS) brightness temperatures were provided by the Vrije Universiteit Amsterdam (VUA) in collaboration with NASA. AMSR-E is a 
Table 1. Catchment daily mean $(\mu)$ /standard deviation $(\sigma)$ of precipitation $(P)$, temperature $(T)$ and reference evapotranspiration $($ ET) in the Murrumbidgee River basin for 2007-2010.

\begin{tabular}{|c|c|c|c|c|c|c|}
\hline & \multicolumn{2}{|c|}{$P\left(\mathrm{~mm} \mathrm{day}^{-1}\right)$} & \multicolumn{2}{|l|}{$T\left({ }^{\circ} \mathrm{C}\right)$} & \multicolumn{2}{|c|}{$\mathrm{ET}\left(\mathrm{mm} \mathrm{day}^{-1}\right)$} \\
\hline & $\begin{array}{l}\text { Local } \\
\mu / \sigma\end{array}$ & $\begin{array}{c}\text { Global } \\
\mu / \sigma\end{array}$ & $\begin{array}{l}\text { Local } \\
\mu / \sigma\end{array}$ & $\begin{array}{c}\text { Global } \\
\mu / \sigma\end{array}$ & $\begin{array}{l}\text { Local } \\
\mu / \sigma\end{array}$ & $\begin{array}{c}\text { Global } \\
\mu / \sigma\end{array}$ \\
\hline 2007 & $1.38 / 3.22$ & $1.36 / 3.19$ & $19.73 / 7.05$ & $16.02 / 6.66$ & $3.98 / 2.13$ & $3.18 / 1.62$ \\
\hline 2008 & $1.24 / 3.19$ & $1.26 / 3.32$ & $18.89 / 6.65$ & $15.18 / 6.24$ & $3.88 / 2.06$ & $3.00 / 1.51$ \\
\hline 2009 & $1.16 / 2.48$ & $1.15 / 2.33$ & $19.82 / 7.46$ & $16.07 / 6.76$ & $4.08 / 2.33$ & $3.24 / 1.83$ \\
\hline 2010 & $2.35 / 5.46$ & $2.45 / 5.19$ & $18.50 / 6.91$ & $15.03 / 6.46$ & $3.69 / 2.04$ & $2.95 / 1.56$ \\
\hline
\end{tabular}

multi-frequency passive microwave radiometer that uses $\mathrm{C}$ $(6.9 \mathrm{GHz})$ and $\mathrm{X}$-band $(10.65$ and $18.7 \mathrm{GHz})$ radiance observations to derive near-surface soil moisture via the LPRM radiative transfer model (Owe et al., 2008; De Jeu et al., 2008). In the present study, C-band AMSR-E data reported on a regular $\sim 50 \mathrm{~km}$ global grid with an observation depth of $2 \mathrm{~cm}$ and a revisit time of 1-3 days was considered (Owe et al., 2008). Brightness temperatures from C-band AMSR$\mathrm{E}$ were downscaled using the smoothing filter-based modulation technique. In this technique, brightness temperatures from the $\mathrm{C}$ band $(\sim 50 \mathrm{~km} \times 50 \mathrm{~km})$ are adjusted based on data from the Ka band $(\sim 10 \mathrm{~km} \times 10 \mathrm{~km})$. From the downscaled C-band AMSR-E brightness temperatures, soil moisture on a $0.08^{\circ} \times 0.08^{\circ}$ spatial resolution is estimated. To improve the quality of the final soil moisture products a precipitation mask is applied (Gevaert et al., 2015).

Soil moisture observations from AMSR-E were compared to the unsaturated zone layer of OSWS and the first of the three vertical layers constituting the soil profile in each grid cell of PCR-GLOBWB. To match the remotely sensed soil moisture observations to the statistics of corresponding hydrological model states for soil water, different strategies can be followed, such as linear or minimum-maximum (MM) matching (Brocca et al., 2011), mean-standard deviation ( $\mu$ $\sigma)$ matching (Draper et al., 2009) and cumulative distribution function (CDF) matching (Reichle and Koster, 2004). In this study, a linear rescaling method was used. The converted satellite soil moisture values $\theta_{\text {new }}\left(\right.$ in $\mathrm{m}^{3} \mathrm{~m}^{-3}$ ) used for assimilation were calculated as

$\theta_{\text {new }}=I_{\min }+\left(\frac{I_{\max }-I_{\min }}{\theta_{\max }-\theta_{\min }}\right)\left(\theta-\theta_{\min }\right)$,

where $I_{\max }$ and $I_{\min }$ are the field capacity and the wilting point of the modelled soil moisture values at each grid cell $\left(\mathrm{m}^{3} \mathrm{~m}^{-3}\right)$ and $\theta_{\max }$ and $\theta_{\min }$ are the maximum and minimum of AMSR-E satellite soil moisture values at the respective grid location (-).

In situ soil moisture observations were obtained from the Australian moisture monitoring network, OzNet (http: //www.oznet.org.au; Smith et al., 2012). A total of 28 soil moisture monitoring stations with daily observations was used in this study for the period January 2007 to Decem-
Table 2. Soil moisture monitoring sites' information.

\begin{tabular}{|c|c|c|c|}
\hline \multirow[t]{2}{*}{ Monitoring site name } & \multicolumn{2}{|c|}{ Location } & \multirow[t]{2}{*}{ Elevation (m) } \\
\hline & Longitude & Latitude & \\
\hline Adelong Creek 1 & 148.11 & -35.50 & 772 \\
\hline Adelong Creek 3 & 148.10 & -35.40 & 472 \\
\hline Adelong Creek 4 & 148.07 & -35.37 & 457 \\
\hline Kyeamba Creek 1 & 147.56 & -35.49 & 437 \\
\hline Kyeamba Creek 4 & 147.60 & -35.43 & 296 \\
\hline Kyeamba Creek 6 & 147.46 & -35.39 & 317 \\
\hline Kyeamba Creek 9 & 147.44 & -35.32 & 241 \\
\hline Kyeamba Creek 12 & 147.49 & -35.23 & 220 \\
\hline Kyeamba Creek 13 & 147.53 & -35.24 & 261 \\
\hline Murrumbidgee catchment 1 & 148.97 & -36.29 & 937 \\
\hline Murrumbidgee catchment 2 & 149.20 & -35.31 & 639 \\
\hline Murrumbidgee catchment 3 & 148.04 & -34.63 & 333 \\
\hline Murrumbidgee catchment 5 & 143.55 & -34.66 & 62 \\
\hline Murrumbidgee catchment 6 & 144.87 & -34.55 & 90 \\
\hline Murrumbidgee catchment 7 & 146.07 & -34.25 & 137 \\
\hline Yanco 1 & 145.85 & -34.63 & 120 \\
\hline Yanco 2 & 146.11 & -34.65 & 130 \\
\hline Yanco 3 & 146.42 & -34.62 & 144 \\
\hline Yanco 4 & 146.02 & -34.72 & 130 \\
\hline Yanco 5 & 146.29 & -34.73 & 136 \\
\hline Yanco 6 & 145.87 & -34.84 & 121 \\
\hline Yanco 7 & 146.12 & -34.85 & 128 \\
\hline Yanco 8 & 146.41 & -34.85 & 149 \\
\hline Yanco 9 & 146.02 & -34.97 & 122 \\
\hline Yanco 10 & 146.31 & -35.01 & 119 \\
\hline Yanco 11 & 145.94 & -35.11 & 113 \\
\hline Yanco 12 & 146.17 & -35.07 & 120 \\
\hline Yanco 13 & 146.31 & -35.09 & 121 \\
\hline
\end{tabular}

ber 2010 (Table 2). Soil moisture monitoring sites were distributed evenly across 10 different study areas around and in the Murrumbidgee River basin, including the northern and eastern fringe of the catchment and those associated with the Yanco, Kyeamba Creek and Adelong Creek sites. The instrumentation at the sites measures moisture content in soil layers from either $0-8$ or $0-5 \mathrm{~cm}$ depth.

\subsubsection{Discharge data}

Discharge observations were provided by the Bureau of Meteorology (BoM) and the Commonwealth Scientific and In- 
Table 3. Hydrometeorological and geographical information of analysed catchments at the Murrumbidgee River basin.

\begin{tabular}{|c|c|c|c|c|c|}
\hline \multirow[t]{2}{*}{ Station no. } & \multirow[t]{2}{*}{ Station name } & \multirow{2}{*}{$\begin{array}{r}\text { Basin area } \\
\left(\mathrm{km}^{2}\right)\end{array}$} & \multicolumn{2}{|c|}{ Outlet location } & \multirow[t]{2}{*}{ Mean flow } \\
\hline & & & Longitude & Latitude $\left(\mathrm{m}^{3} \mathrm{~s}^{-1}\right)$ & \\
\hline \multicolumn{6}{|c|}{ Assimilation } \\
\hline 410088 & Goodradigbee River at Brindabella & 419.66 & 148.73 & -35.42 & 3.719 \\
\hline 410062 & Numeralla River at Numeralla School & 691.38 & 149.35 & -36.18 & 1.164 \\
\hline 410024 & Goodradigbee River at Wee Jasper (Kashmir) & 1050.60 & 148.69 & -35.17 & 5.805 \\
\hline 410044 & Muttama Creek at Coolac & 1058.49 & 148.16 & -34.93 & 1.072 \\
\hline 410033 & Murrumbidgee River at Mittagang Crossing & 1809.84 & 149.09 & -36.16 & 2.228 \\
\hline 410761 & Murrumbidgee River below Lobbs Hole Creek & 9332.28 & 149.10 & -35.54 & 5.463 \\
\hline 410130 & Murrumbidgee River at D/S Balranald weir & 28651.21 & 143.49 & -34.67 & 10.113 \\
\hline 410023 & Murrumbidgee River at D/S Berembed weir & 34133.07 & 146.84 & -34.88 & 38.449 \\
\hline 410021 & Murrumbidgee River at Darlington Point & 37804.78 & 146.00 & -34.57 & 29.899 \\
\hline 410040 & Murrumbidgee River at D/S Maude weir & 43110.97 & 144.30 & -34.48 & 16.888 \\
\hline \multicolumn{6}{|c|}{ Evaluation } \\
\hline 410107 & Mountain Creek at Mountain Creek & 140.54 & 148.84 & -35.03 & 1.078 \\
\hline 410705 & Molonglo River at Burbong & 350.22 & 149.31 & -35.34 & 0.591 \\
\hline 410048 & Kyeamba Creek at Ladysmith & 350.30 & 147.53 & -35.20 & 2.41 \\
\hline 410038 & Adjungbilly Creek at Darbalara & 390.89 & 148.25 & -35.02 & 1.494 \\
\hline 410734 & Queanbeyan River at Tinderry & 557.73 & 149.35 & -35.61 & 0.893 \\
\hline 410057 & Goobarragandra River at Lacmalac & 559.77 & 148.35 & -35.33 & 4.964 \\
\hline 410026 & Yass River at Yass & 1226.98 & 148.91 & -34.84 & 1.198 \\
\hline 410091 & Billabong Creek at Walbundrie & 2859.77 & 146.72 & -35.69 & 2.113 \\
\hline 410050 & Murrumbidgee River at Billilingra & 3353.91 & 149.13 & -35.98 & 3.836 \\
\hline 410001 & Murrumbidgee River at Wagga Wagga & 39856.21 & 147.37 & -35.10 & 59.638 \\
\hline 410005 & Murrumbidgee River at Narrandera & 45321.40 & 146.55 & -34.76 & 48.074 \\
\hline 410078 & Murrumbidgee River at Carrathool & 69854.30 & 145.42 & -34.35 & 27.057 \\
\hline 410136 & Murrumbidgee River at D/S Hay weir & 73241.50 & 144.71 & -34.52 & 25.243 \\
\hline
\end{tabular}

dustrial Research Organisation (CSIRO), under the Water Information $\mathrm{R}+\mathrm{D}$ Alliance (WIRADA). A total of 23 discharge monitoring stations with daily observations in the Murrumbidgee River and its main tributaries were available for the period January 2007 to December 2010. To ensure an independent evaluation of model simulations after the assimilation, a split sample approach of streamflow stations was used (e.g. Lee et al., 2012; Rakovec et al., 2012; Wanders et al., 2014b). The discharge of 10 stations was used for assimilation into the large-scale hydrological model, the remaining 13 stations were used for evaluation. Assimilation and evaluation stations were selected such that they were equally distributed over the catchment and situated both in small tributaries and the main Murrumbidgee River. Figure 1 shows a map with the discharge locations. Table 3 summarises some key hydrological data.

\subsection{Data assimilation}

\subsubsection{Ensemble Kalman filter}

The ensemble Kalman filter (EnKF) is a sequential data assimilation method evolved from the standard Kalman filter
(Evensen, 1994) that has been used previously for assimilation of observations into land surface and hydrological models (Chen et al., 2011; Draper et al., 2011; Wanders et al., 2014a; Tangdamrongsub et al., 2015). It is a Monte Carlobased approach that integrates an ensemble of model states forward in time to represent the error statistics of the model estimate when observations are assimilated (Burgers et al., 1998; Evensen, 2003). The state equation in a discrete form is given as

$x_{t+1}=f\left(x_{t}, F_{t+1}, p, \varepsilon_{t}\right)$,

where $f$ are the dynamical model equations that represents the hydrological processes in the system, $x_{t}$ is the model state at time $t, F_{t}$ is the forcing at time $t$ (e.g. precipitation and temperature), $p$ are the model parameters and $\varepsilon_{t}$ is the model error. To assimilate observations into the hydrological model, the already mentioned observations, downscaled remotely sensed AMSR-E soil moisture and discharge, can be linearly described as

$y_{t}=H_{t} x_{t}+\epsilon$,

where $y_{t}$ is the observations' vector, $H$ is the observation model or operator that relates the model states $x_{t}$ to the ob- 
servations $y$, and $\epsilon$ is the random noise with a zero mean and an error given by the observations' error covariance ma$\operatorname{trix} \mathbf{R}_{t}$.

The EnKF calculates the analysis at each time $t, x_{t}^{\mathrm{a}}$, of the model forecast, $x_{t}^{\mathrm{f}}$, as

$x_{t}^{\mathrm{a}}=x_{t}^{\mathrm{f}}+K_{t}\left[y_{t}-H_{t}\left(x_{t}^{\mathrm{f}}\right)\right]$,

where $K_{t}$ is defined as the Kalman gain

$K_{t}=\mathbf{P}_{t} \mathbf{H}_{t}^{\mathrm{T}}\left(\mathbf{R}_{t}+H_{t} \mathbf{P}_{t} \mathbf{H}_{t}^{\mathrm{T}}\right)^{-1}$,

with $\mathbf{H}_{t}^{\mathrm{T}}$ the transpose matrix of the observation model at time $t$ (which is equal to the identity matrix after linear rescaling) and $\mathbf{P}_{t}$ the state error covariance matrix of the model prediction calculated from the spread between the different ensemble members given as

$\mathbf{P}_{t}=\frac{\sum_{n=1}^{N}\left(x_{n}^{\mathrm{f}}-\overline{x^{\mathrm{f}}}\right)\left(x_{n}^{\mathrm{f}}-\overline{x^{\mathrm{f}}}\right)^{\mathrm{T}}}{N-1}$,

where $\overline{x^{\mathrm{f}}}$ is the ensemble average of model simulations and $N$ the number of ensemble members considered.

\subsubsection{Assimilating soil moisture and discharge observations}

In this study, the EnKF was applied to update state variables of the large-scale hydrological model, PCR-GLOBWB, on each daily time step using downscaled remotely sensed AMSR-E soil moisture and discharge observations. We used 100 ensemble members and all the observations were calculated and assimilated at each $0.08^{\circ}$ model grid cell for each day that observations are available. The EnKF has been implemented in the PCRaster modelling environment (Karssenberg et al., 2010).

A total of eight different data assimilation scenarios with PCR-GLOBWB were intercompared and compared to the OSWS estimates without any data assimilation. The data assimilation (DA) scenarios are described in Table 4, indicating the meteorological forcing and the observations used in each scenario. Simulations forced with local meteorological data are denoted with LOCAL and simulations forced with global meteorological data are denoted with GLOBAL. Independent assimilation of discharge (GLOBWB_Q) and soil moisture (GLOBWB_SM) were investigated, as well as the joint assimilation of both observation types (GLOBWB_SM+Q).

In the EnKF, to account for model and observations uncertainty, stochastic noise can be introduced in model forcing data, parameters, soil moisture and discharge observations. For the local and global meteorological forcing, the precipitation was perturbed with additive Gaussian white noise with standard deviation of $10 \%$ of the nominal value (Adam and Lettenmaier, 2003; Hijmans et al., 2005). The errors were assumed to be spatially uncorrelated. For the assimilation of the satellite soil moisture data, spatial information on the measurement error covariance $R$ (Eq. 5) was required. The structure of $R$ was determined from estimates of Wanders et al. (2012) over Spain, obtained by using high-resolution modelling of the unsaturated zone. The average standard error of AMSR-E is $0.049 \mathrm{~m}^{3} \mathrm{~m}^{-3}$. The error covariance between the discharge observations was set to zero while the standard error for the discharge observations was assumed to be $10 \%$ of the discharge. It was additionally assumed that the covariance between the satellite soil moisture observations and discharge observations equals zero. Some of the assumptions described in this section for data assimilation were investigated through a preliminary sensitivity analysis including the number of ensemble members and the standard errors of precipitation and discharge (Figs. S1-S6 in the Supplement).

\subsection{Evaluation}

The impact of assimilating discharge and soil moisture observations into the large-scale hydrological model PCRGLOBWB, compared with the locally calibrated model OSWS, is separately analysed: firstly, on soil moisture estimates and secondly, on discharge estimates. A common regular $0.08^{\circ} \times 0.08^{\circ}$ grid $(\sim 10 \mathrm{~km})$ was adopted for the intercomparison of the two different resolution hydrological models estimates. For this purpose, OSWS estimates were upscaled with a linear resampling from $0.01^{\circ} \times 0.01^{\circ}(\sim 1 \mathrm{~km})$ to $0.08^{\circ} \times 0.08^{\circ}(\sim 10 \mathrm{~km})$.

Results were produced for each of the 23 locations listed in Table 3. For practical reasons, the following section includes results for a limited number of evaluation locations only, both in the Murrumbidgee River and its tributaries. This combination thus comprises stations with varying sizes of contributing area.

To understand and intercompare the performance of the different data assimilation scenarios described in Table 3, an extensive evaluation was carried out, including the calculation of various evaluation metrics, such as root mean squared error (RMSE), mean absolute error (MAE), Pearson correlation coefficient $(r)$ and Nash-Sutcliffe efficiency (NSE Nash and Sutcliffe, 1970).

\section{Results}

\subsection{Impact of assimilation on soil moisture estimates}

The time series of simulated soil moisture for $0-5 \mathrm{~cm}$ for each data assimilation scenario and downscaled AMSR-E observations for the time period January 2008-May 2009 at gauging station no. 410057 (mountainous region) are shown in Fig. 5.

The use of global forcing data produces a different dynamic response of soil moisture estimates compared to the 
Table 4. Data assimilation scenarios including abbreviations, forcing data, hydrological model and assimilated observations.

\begin{tabular}{llll}
\hline Identifier & \multicolumn{2}{c}{ DA scenarios } \\
\cline { 2 - 4 } & Forcing data & Hydrological model & Assimilated observations \\
\hline LOCAL GLOBWB_OL & Local (AWAP) & PCR-GLOBWB & Open loop (none) \\
LOCAL GLOBWB_Q & & & Discharge stations \\
LOCAL GLOBWB_SM & & & AMSR-E soil moisture \\
LOCAL GLOBWB_SM+Q & & OpenStreams wflow_sbm (OSWS) & Discharge stations and AMSR-E soil moisture \\
LOCAL OSWS & & Open loop (none) \\
GLOBAL GLOBWB_OL & Global (WFDEI) & PCR-GLOBWB & Open lischarge stations \\
GLOBAL GLOBWB_Q & & & AMSR-E soil moisture \\
GLOBAL GLOBWB_SM & & & Discharge stations and AMSR-E soil moisture \\
GLOBAL GLOBWB_SM+Q & & OpenStreams wflow_sbm (OSWS) & None \\
GLOBAL OSWS & &
\end{tabular}

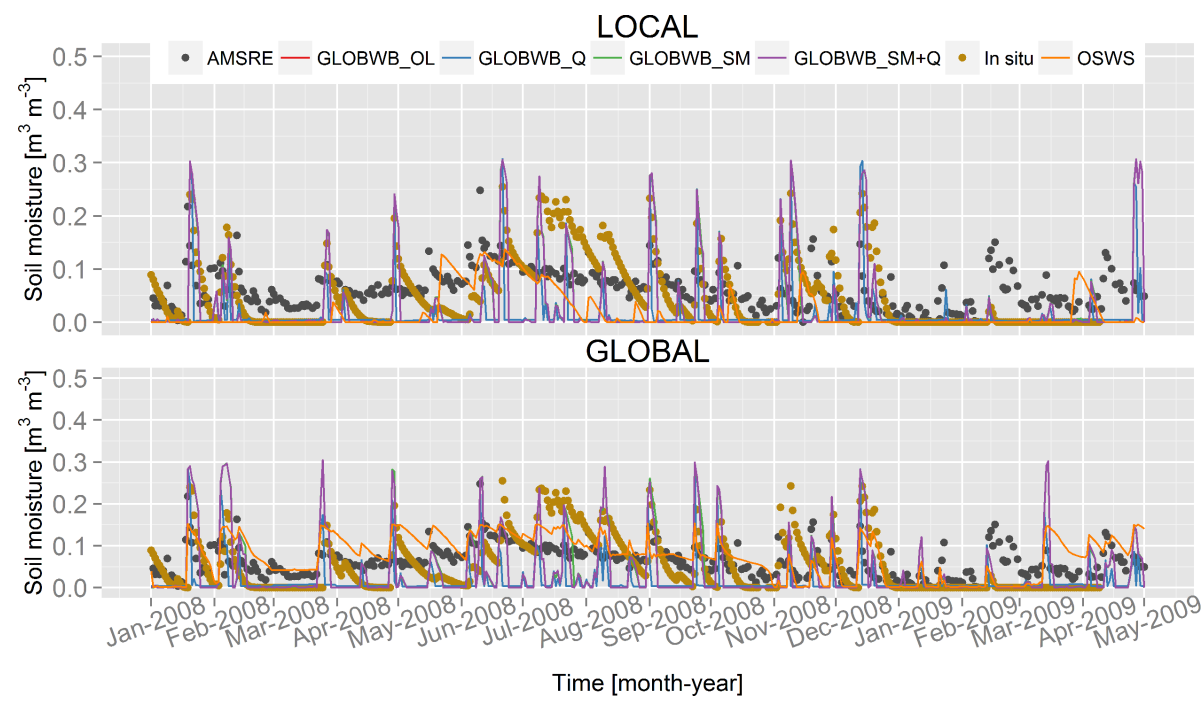

Figure 5. Simulated and observed soil moisture estimates at gauging station no. 410057 in a tributary of the Murrumbidgee River for the time period January 2008-May 2009. The upper panel shows soil moisture time series when local data are used as model forcing. Soil moisture time series obtained with the global forced models are shown in the lower panel. Each panel contains results for each data assimilation scenario plotted with different coloured lines (OSWS - orange, GLOBWB_Q - blue, GLOBWB_SM - green and GLOBWB_SM+Q purple), downscaled AMSR-E observations with dark grey points and in situ soil moisture observations with dark yellow points.

local forcing data. This fact is due to the discrepancies between both meteorological data sets, which govern the water exchange processes between the top layer and the atmosphere (precipitation, evapotranspiration and temperature).

Even though global precipitation quite accurately depicts the overall character of the precipitation (daily mean values of the local and global precipitations show similar spatial distributions and magnitudes; see Sect. 2.3.1), the global precipitation misses specific rainfall events at particular days and locations due to its lower resolution. This is especially important for warm season precipitation and regions in mountainous terrain (e.g. gauging station no. 410057 in Fig. 5), which are dominated by convective storms. The differences in precipitation are reflected in soil moisture estimates of both hydrological models and their impact is higher in PCR-
GLOBWB estimates. When PCR-GLOBWB is forced with local data, soil moisture estimates produce patterns with a more accurate description of the small-scale variability of the observations in time. Whereas when global forcing is used, soil moisture results in a smoother estimation of the observations.

A total of eight different data assimilation scenarios were investigated, with global and local forcing data (Table 3). In the OL scenario, no data are assimilated into the model to correct intermediate model states. In this first scenario, soil moisture observations are underestimated when local forcing is used. The assimilation of discharge observations, Q scenario, results in similar soil moisture estimates compared to the OL scenario, as expected. This similarity is caused by the assimilation procedure which constrains the model to fol- 

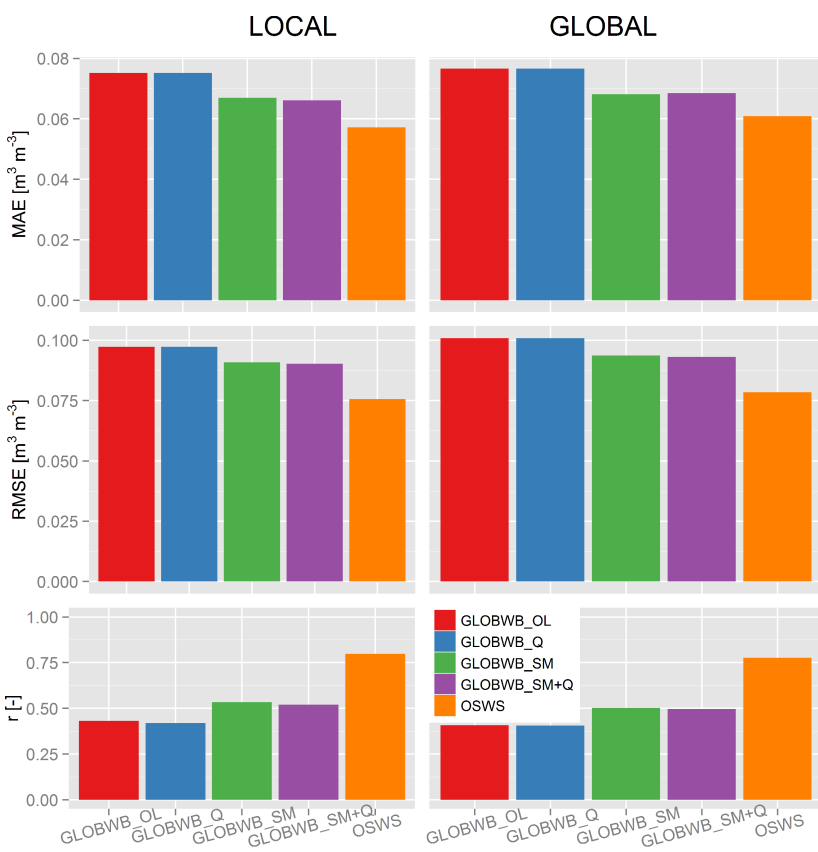

Figure 6. Evaluation results of the catchment daily means of soil moisture in the Murrumbidgee River basin. In the rows, three different evaluation metrics are shown; from top to bottom, these are the MAE, the RMSE and $r$. Columns show various forcing data: local and global. (For clarity, the exact values are included in Table A1.)

low the discharge observations directly affecting groundwater and routing processes, which are a poor reflection of the upper soil moisture content from 0 to $5 \mathrm{~cm}$. In contrast, the assimilation of soil moisture observations in SM and SM_Q scenarios produces a reduction of the negative bias, improving the soil moisture estimates, especially when local forcing is used.

Figure 6 shows the impact of each data assimilation scenario on the considered evaluation metrics (RMSE, MAE and $r$ ). Results of the catchment daily mean values are shown. Each histogram shows the evaluation metric on the vertical axis vs. the data assimilation scenarios on the horizontal axis. Figure 6 consists of a matrix of multiple panels, with rows showing the three considered evaluation metrics and columns showing local and global forcing data.

From this figure, some general observations can be made. Evaluation results show differences between the results from local and global forcing of the models. For example, the use of local instead of global forcing produces a decrease of 4 and $2 \%$ in RMSE and MAE, respectively, and an increase of $6 \%$ in $r$, when the OL scenario in PCR-GLOBWB is considered.

The large-scale model, PCR-GLOBWB, without data assimilation shows a poorer performance than the locally calibrated model OSWS on soil moisture predictions. Assimilating discharge observations ( $\mathrm{Q}$ scenario) does not lead to an
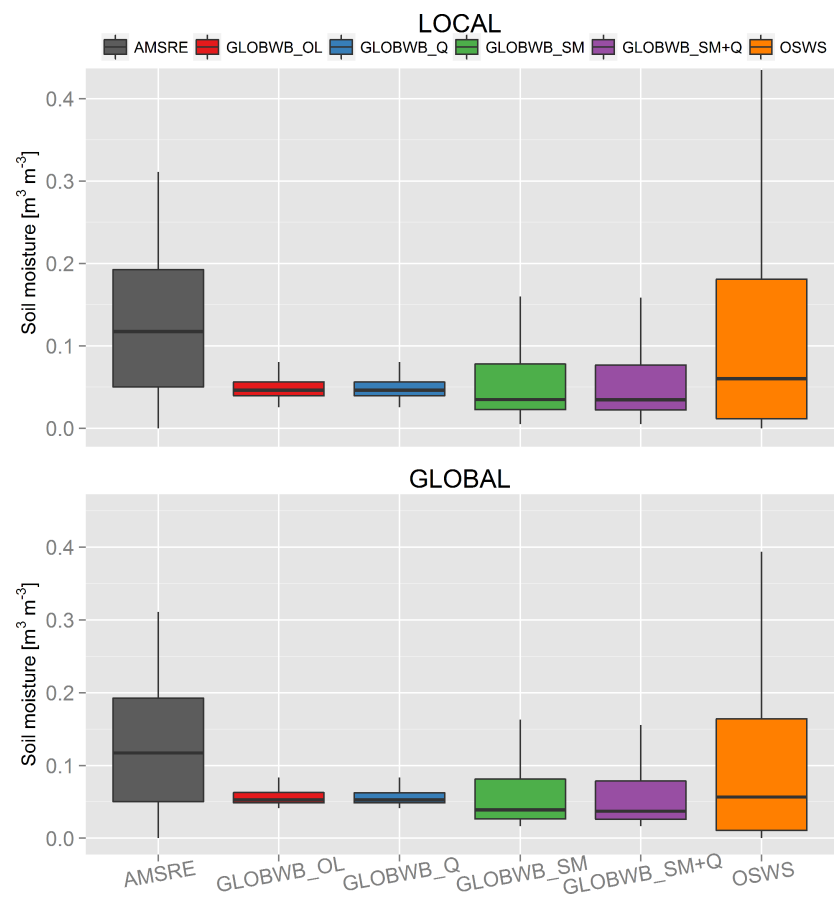

Figure 7. Boxplots of the catchment daily means of soil moisture in the Murrumbidgee River basin. The upper panel shows soil moisture when local data are used as model forcing. Soil moisture obtained with the global forced models is shown in the lower panel. Boxplots of each panel illustrate the first and third quantile ranges (box), the median (dark line) and the maximum-minimum range (whiskers) of soil moisture estimates.

improvement of soil moisture estimates, whereas downscaled AMSR-E soil moisture observations assimilation (SM scenario) results in an increase of $r$ and a decrease of RMSE and MAE. Therefore, after assimilating soil moisture observations, evaluation results of PCR-GLOBWB and OSWS are closer to each other. For example, percent differences in RMSE between both models are reduced from $22 \%$ (LOCAL GLOBWB_OL and LOCAL OSWS) to $16 \%$ (LOCAL GLOBWB_SM+Q and LOCAL OSWS) and MAE from $14 \%$ (LOCAL GLOBWB_OL and LOCAL OSWS) to $16 \%$ (LOCAL GLOBWB_SM+Q and LOCAL OSWS). However, the reduction in the differences between PCRGLOBWB and OSWS performances due to the assimilation of soil moisture and streamflow observations does not mean that both models perform similarly. Maximum $r$ values obtained with PCR-GLOBWB are $\sim 0.5$, whereas for OSWS maximum $r$ values of 0.7 are reached.

Additionally, boxplots of the catchment daily mean values are included in Fig. 7 considering local (upper panel) and global (lower panel) forcing. The assimilation of soil moisture observations leads to an evident improvement in the statistical distribution of PCR-GLOBWB soil moisture estimates, reducing the differences in dispersion with the observations. 

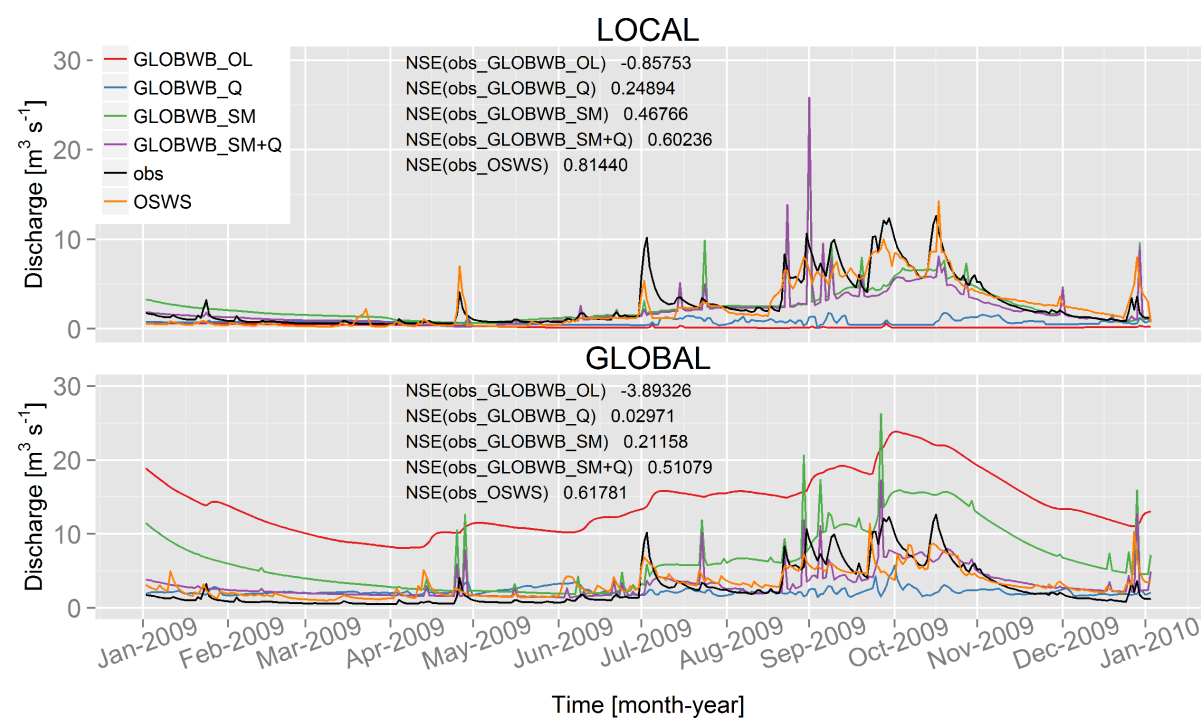

Figure 8. Simulated and observed streamflow estimates at gauging station no. 410088 in a tributary of the Murrumbidgee River for the time period January 2009-January 2010. The upper panel shows streamflow when local data are used as model forcing. Streamflow obtained with the global forced models is shown in the lower panel. Each panel contains results for each data assimilation scenario and the observed streamflow estimates plotted with different coloured lines (OSWS - orange, GLOBWB_OL - red, GLOBWB_Q - blue, GLOBWB_SM green, GLOBWB_SM+Q - purple and obs - black). The ensemble mean is given for each data assimilation scenario.

Assimilating soil moisture observations and forcing the model with high-spatial-resolution meteorological data sets impacts the quality of soil moisture estimates with PCRGLOBWB to a similar extent. Results indicate that the highest improved performance is achieved when their combination occurs, i.e. soil moisture observations are assimilated into a model driven by local forcing data (LOCAL GLOBWB_SM and LOCAL GLOBWB_SM+Q scenarios).

\subsection{Impact of assimilation on streamflow estimates}

The simulated and observed streamflow estimates at gauging station no. 410088 are shown in Fig. 8. From this figure, it is clear that the peaks in streamflow are poorly estimated by PCR-GLOBWB, whereas OSWS is able to capture them with higher accuracy, independently of the forcing data used. This is most probably explained by the higher resolution and the calibration of model parameters for the study.

Differences between local and global forcing data (see Sect. 2.3.1) are reflected in differences in streamflow estimates from both models. When global data are used, evapotranspiration is lower; hence, a higher amount of water is introduced into the models, resulting in higher streamflow estimates. By assimilating discharge and soil moisture observations, intermediate hydrological processes, including groundwater state, percolation and surface runoff, among others, are corrected and errors in forcing data are reduced to improve streamflow predictions (e.g. November 2008). The best performance is achieved when soil moisture and discharge data are jointly assimilated.
To further analyse and quantify the influence of each data assimilation scenario on streamflow estimates, the evaluation metrics (RMSE, MAE, $r$ and NSE) were calculated and included for multiple discharge locations in Fig. 9.

The highest $r$ and NSE and the lowest RMSEs and MAEs are obtained when models are forced with local meteorological data. The use of global forcing data leads to a reduction in performance, which is more significant for the largescale than for the local-scale model. Without assimilation, forcing PCR-GLOBWB with local data (L_OL) instead of global data (GLOBAL GLOBWB_OL) results in an increase of $80 \%$ in $r$ and a decrease of $70 \%$ in RMSE and $72 \%$ in MAE on average. OSWS also improves its streamflow estimates but to a lesser degree, with increases of $7 \%$ in $r$ and decreases of $28 \%$ in RMSE and $43 \%$ in MAE (LOCAL OSWS and GLOBAL OSWS).

Both observations' assimilation, discharge and soil moisture separately (Q and SM), improve streamflow models' estimates. The highest improvement is achieved when both observations are assimilated into the model (GLOBWB $\mathrm{SM}+\mathrm{Q}$ ), as expected. The improvement is higher when soil moisture observations (SM) are assimilated than the case of discharge assimilation alone (Q). For example, in terms of $r$, GLOBAL GLOBWB_SM scenario results in an increase of $20 \%$ and G_Q scenario of $5 \%$ relative to GLOBAL GLOBWB_OL scenario at gauging station no. 410107. Some possible explanations could be the finer resolution of AMSR-E soil moisture observations and/or the basin hydrological features, which characterize it as a catchment mainly driven by direct runoff, where the highest contribution to the 


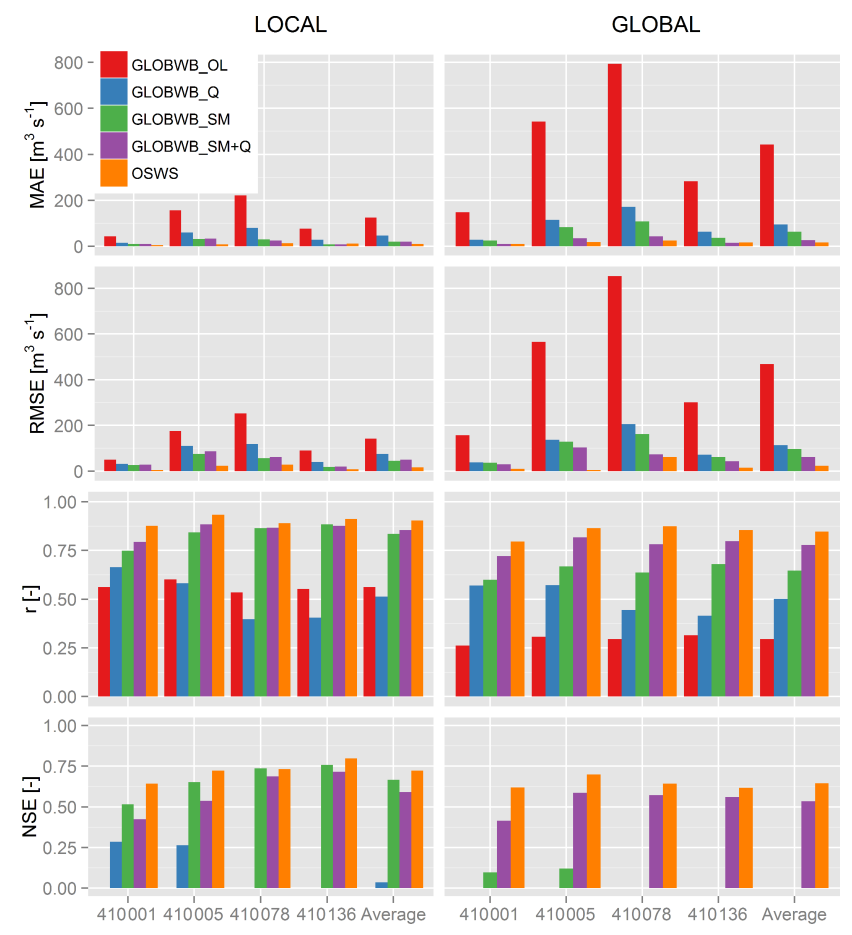

Figure 9. Evaluation results for streamflow estimates at station nos. 410001, 410005, 410078 and 410136 in the Murrumbidgee River. Average values calculated across those locations are shown in the rightmost bar of each histogram. In the rows, four different evaluation metrics are shown; from top to bottom, these are the MAE, RMSE, $r$ and the NSE. Columns show various forcing data: local and global.

total runoff comes from the upper soil layer and not from the groundwater zone.

The largest improvements were found at gauging stations in the main channel of the Murrumbidgee River, such as station no. 410001 where assimilating soil moisture and discharge observations increases $r$ from 0.56 to 0.79 and decreases RMSE and MAE from 49.54 to $28.77 \mathrm{~m}^{3} \mathrm{~s}^{-1}$ and from 43.85 to $10.76 \mathrm{~m}^{3} \mathrm{~s}^{-1}$, i.e. comparing the LOCAL GLOBWB_OL and LOCAL GLOBWB_SM+Q scenarios. This improvement is more significant when the model is forced with global data than with local data. At station 410001, RMSE varies from 157.62 to $29.01 \mathrm{~m}^{3} \mathrm{~s}^{-1}$, MAE from 148.29 to $10.88 \mathrm{~m}^{3} \mathrm{~s}^{-1}$ and $r$ from 0.26 to 0.72 when GLOBAL GLOBWB_OL and GLOBAL GLOBWB_SM+Q scenarios are compared.

Boxplots of streamflow estimates are included in Fig. 10. The results clearly show that, compared to the observed streamflow, the median values of PCR-GLOBWB streamflow without data assimilation are very biased. The greatest amount of spread is observed between OL scenarios and observations, across all stations. Every data assimilation scenario $(\mathrm{Q}, \mathrm{SM}$ and $\mathrm{SM}+\mathrm{Q})$ shows improvement in the statis-
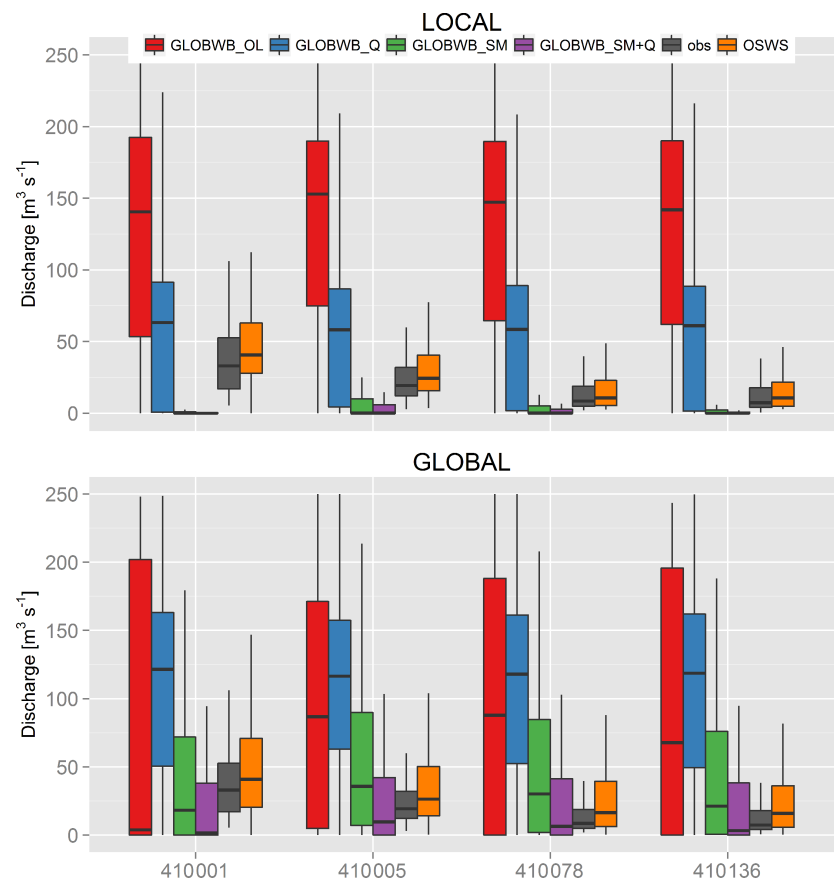

Figure 10. Boxplots of streamflow estimates at station nos. 410001, 410005, 410078 and 410136 in the Murrumbidgee River. The upper panel shows streamflow when local data are used as model forcing. Streamflow obtained with the global forced models is shown in the lower panel. Boxplots of each panel illustrate the first and third quantile ranges (box), the median (dark line) and the maximumminimum range (whiskers) of streamflow estimates.

tics of streamflow, correcting not only its median value but also the overestimation.

In contrast with the soil moisture evaluation results, Figs. 8-10 indicate that for streamflow the use of local forcing provides a larger improvement than assimilating soil moisture and discharge observations. Using a global model with local forcing and assimilating satellite soil moisture data yields streamflow predictions comparable to a local model with local forcing along the main river of this catchment. Moreover, also on the main channel, a global model with global forcing may still yield reasonable results as long as both discharge data and soil moisture data are assimilated.

\section{Discussion}

PCR-GLOBWB poorly estimates streamflow and soil moisture, when forced either with high- or coarse-spatialresolution forcing data, without data assimilation. The derivation of the hydrological model parameters from hydrogeological information at a global scale could be a possible explanation. From the initial scenarios without assimilation, it can be inferred that there is significant space for improvements when discharge and soil moisture observations are assimilated. An alternative route to data assimilation to 
improve model estimates would be to locally calibrate PCRGLOBWB using discharge observations from in situ gauging stations. The improvement achieved through model parameters calibration would be possibly even higher than when soil moisture and streamflow observations are assimilated into the model (Wanders et al., 2014b). However, the present study aims to be an attempt at providing hydrological estimations with a global model that could be also used in ungauged river basins where scarce in situ data are available.

The joint assimilation of discharge and downscaled satellite soil moisture observations produces the largest improvement on PCR-GLOBWB streamflow estimates (20\% reduction in RMSE). These results agree with the findings made by Wanders et al. (2014a) in the Upper Danube and are also in line with the expectations where more observations lead to a better constrained model simulation.

A major finding of this study is the positive impact of assimilating soil moisture observations on the streamflow estimates, compared to the independent discharge assimilation. The estimations of a large-scale hydrological model driven with coarse-resolution forcing data are improved using globally available remotely sensed soil moisture observations. This creates an opportunity for improved global model-based streamflow estimations as a result of the assimilation of remotely sensed soil moisture observations into large-scale hydrological models. Additionally, the adopted methodology has the advantage that it is applicable in river basins all over the world independently of the availability of in situ hydrometeorological information.

The variable effectiveness of soil moisture assimilation has been previously reported in literature. Whereas some studies found improvements (Draper et al., 2011; Wanders et al., 2014b), others obtained mixed or unsatisfactory results (Crow et al., 2005). The scale of soil moisture observations, the dominant runoff processes in the study basin and the model structure and parameter uncertainties may partly explain this variability. In this particular study, the novel use of a finer-spatial-resolution satellite soil moisture product together with the climate and hydrogeological characteristics of the catchment could be a possible explanation of the positive impact of soil moisture assimilation. Renzullo et al. (2014) assimilated satellite soil moisture observations from multiple sensors (ASCAT and AMSR-E) obtained at scales coarser than the model (AWRA-L) resolution. In the present study, the scale of soil moisture observations coincides with the model scale. A specific analysis of the impact on streamflow and soil moisture estimates of assimilating non-downscaled AMSR-E soil moisture assimilation could be a possible route to further investigate the effect of different spatial-resolution soil moisture products. To this end, AMSR-E soil moisture observations at the original spatial resolution were assimilated into PCR-GLOBWB and results analysis presented in this study were reproduced. Results showed that the assimilation of non-downscaled soil moisture observations has a positive impact on soil moisture and discharge estimates, but this improvement is smaller compared to the assimilation of the downscaled soil moisture estimates (Figs. S7 and S8). Moreover, runoff in the Murrumbidgee River basin is mainly dominated by direct runoff processes, with reduced contribution from the groundwater zone (Green et al., 2011). These catchment conditions, together with their representation in the model structure are most likely responsible for the added value of assimilating soil moisture. There may be merit in analysing these scenarios in future research studies.

For the assimilation of AMSR-E soil moisture observations, spatial information on the measurement error covariance $R$ (Eq. 5) was based on results from previous studies over Spain (Wanders et al., 2012). Our philosophy was to set the AMSR-E errors to realistic values determined and validated in previous studies, so that all the required information was already available. The determination of AMSR-E observations uncertainty specifically over the Murrumbidgee River basin with physically based modelling or in situ soil moisture measurements (Su et al., 2013) could be further investigated. In addition, a linear rescaling method was used to match AMSR-E soil moisture observations to the statistics of model states related with soil water. Different matching strategies could be applied in future studies. To account for model uncertainty, stochastic noise in precipitation data was introduced. A sensitivity analysis on model parameters could be another possible approach.

Meteorological data play a key role in soil moisture and discharge model estimates. The various model and data assimilation options were evaluated under both high- and lowresolution meteorological forcing. In general, the higher spatial resolution and the higher quality of the local forcing data results in better model predictions (PCR-GLOBWB and OSWS) of both soil moisture and streamflow. The coarse resolution of the global forcing could lead to failures to detect extreme rainfall events or differences at specific regions, such as mountainous areas. Recent studies have developed several downscaling procedures, e.g. geostatistical methods of blending satellite and gauge data (Chappell et al., 2013), that could improve model predictions when global forcing is used.

To improve the representation of the global water cycle using global hydrological models, one could follow multiple strategies: improve the quality and quantity of ground observation, increase the spatial resolution of the global models or obtain more detailed information on the catchment properties (e.g. soil data). Another way forward is the assimilation of observations and the use of high-spatial-resolution meteorological data to bridge the gap between the different spatial scales, for which large-scale hydrological models are designed, and the river basin scale. The advantage of this approach is that it provides a global improvement of the hydrological simulation and the satellite data often have a global coverage. In this study, we show the potential gain in model accuracy of using remotely sensed observations. Pre- 
vious studies on the potential gain of satellite observations for global and continental hydrological models agree with the obtained results in the present study (Andreadis and Lettenmaier, 2006; Lievens et al., 2015).

\section{Conclusions}

The study investigates the influence of discharge and soil moisture assimilation on the accuracy of large-scale model (PCR-GLOBWB) predictions, when driven by meteorological forcing data sets of high and coarse resolution, compared with local-scale model (OSWS) estimations.

Results show poor PCR-GLOBWB streamflow and soil moisture estimates when no observations are assimilated. The assimilation of soil moisture observations results in the largest improvement of the model estimates of streamflow. The joint assimilation of both streamflow and downscaled soil moisture observations leads to further improvement in streamflow simulations (20\% reduction in RMSE).

In general, the higher spatial resolution of the local forcing data results in better models predictions of both soil moisture and streamflow. The added value of using higherspatial-resolution forcing data is more significant for PCRGLOBWB than for OSWS. When the impact on model accuracy of assimilating observations and forcing the models with higher-spatial-resolution data are compared, the latter leads to a more substantial improvement of streamflow predictions.
Furthermore, results show that the added contribution of data assimilation, for both soil moisture and streamflow, is more pronounced when the global meteorological data are used to force the models. This is caused by the higher uncertainty and coarser resolution of the global forcing.

The greatest benefit is obtained when local coarseresolution forcing data are used in combination with streamflow and soil moisture observations' assimilation into the large-scale hydrological model, PCR-GLOBWB.

In conclusion, the present research study shows that data assimilation of high-resolution soil moisture succeeds in resolving shortcomings that exist nowadays in global hydrological models and can partly overcome the difference in model performance between a large-scale hydrological model driven by coarse-resolution forcing data and a localscale model forced with higher-resolution meteorological data. Moreover, it demonstrates that further investments and improvements in remotely sensed observations, especially in soil moisture products can benefit large-scale hydrological model predictions and bring these closer to those obtained from local-scale hydrological modelling. 
Appendix A: Evaluation results of the catchment daily means of soil moisture

Table A1. Evaluation results of the catchment daily means of soil moisture estimates (the exact values of Fig. 6 are included in this table for clarification).

\begin{tabular}{lcccccccc}
\hline & \multicolumn{3}{c}{ Local } & & \multicolumn{3}{c}{ Global } \\
\cline { 2 - 3 } & $\begin{array}{c}\text { RMSE } \\
\left(\mathrm{m}^{3} \mathrm{~m}^{-3}\right)\end{array}$ & $\begin{array}{c}\text { MAE } \\
\left(\mathrm{m}^{3} \mathrm{~m}^{-3}\right)\end{array}$ & $\begin{array}{c}r \\
(-)\end{array}$ & & $\begin{array}{c}\text { RMSE } \\
\left(\mathrm{m}^{3} \mathrm{~m}^{-3}\right)\end{array}$ & $\begin{array}{c}\text { MAE } \\
\left(\mathrm{m}^{3} \mathrm{~m}^{-3}\right)\end{array}$ & $\begin{array}{c}r \\
(-)\end{array}$ \\
\hline OSWS & 0.07571 & 0.05716 & 0.79865 & & 0.07854 & 0.06082 & 0.77603 \\
GLOBWB_OL & 0.09735 & 0.07520 & 0.43071 & & 0.10094 & 0.07662 & 0.40715 \\
GLOBWB_Q & 0.09738 & 0.07523 & 0.43041 & & 0.10095 & 0.07664 & 0.40652 \\
GLOBWB_SM & 0.09085 & 0.06699 & 0.53452 & & 0.09372 & & 0.06811 & 0.50230 \\
GLOBWB_SM+Q & 0.09032 & 0.06609 & 0.52085 & & 0.09302 & & 0.06845 & 0.49623 \\
\hline
\end{tabular}




\section{The Supplement related to this article is available online at doi:10.5194/hess-20-3059-2016-supplement.}

Acknowledgement. This research received funding from the European Union Seventh Framework Programme (FP7/2007-2013) under grant agreement no. 603608, Global Earth Observation for integrated water resource assessment: eartH2Observe. The work of N. Wanders was supported by NWO (GO-AO/30) and Rubicon grant (825.15.003). We would like to thank CSIRO in Canberra, ACT, Australia for their active collaboration and constant engagement in the present research project. The authors also want to thank Anouk Gevaert for providing the downscaled AMSR-E soil moisture observations. Geert Sterk is acknowledged for productive comments and discussions on this investigation.

Edited by: G. Jewitt

Reviewed by: two anonymous referees

\section{References}

Adam, J. C. and Lettenmaier, D. P.: Adjustment of global gridded precipitation for systematic bias, J. Geophys. Res.-Atmos., 108, 4257, doi:10.1029/2002JD002499, 2003.

Alcamo, J., Döll, P., Henrichs, T., Kaspar, F., Lehner, B., Rösch, T., and Siebert, S.: Development and testing of the WaterGAP 2 global model of water use and availability, Hydrolog. Sci. J., 48, 317-337, 2003.

Allen, R. G., Pereira, L. S., Raes, D., and Smith, M.: Crop evapotranspiration - Guidelines for computing crop water requirements, FAO Irrigation and Drainage Paper 56, FAO, Rome, 300 pp., 1998.

Alvarez-Garreton, C., Ryu, D., Western, A. W., Su, C.-H., Crow, W. T., Robertson, D. E., and Leahy, C.: Improving operational flood ensemble prediction by the assimilation of satellite soil moisture: comparison between lumped and semi-distributed schemes, Hydrol. Earth Syst. Sci., 19, 1659-1676, doi:10.5194/hess-19-16592015, 2015.

Andreadis, K. M. and Lettenmaier, D. P.: Assimilating remotely sensed snow observations into a macroscale hydrology model, Adv. Water Resour., 29, 872-886, 2006.

Atkinson, P. M.: Downscaling in remote sensing, Int. J. Appl. Earth Obs., 22, 106-114, 2013.

Aubert, D., Loumagne, C., and Oudin, L.: Sequential assimilation of soil moisture and streamflow data in a conceptual rainfall runoff model, J. Hydrol., 280, 145-161, 2003.

Balsamo, G., Beljaars, A., Scipal, K., Viterbo, P., van den Hurk, B., Hirschi, M., and Betts, A. K.: A revised hydrology for the ECMWF model: verification from field site to terrestrial water storage and impact in the integrated forecast system, J. Hydrometeorol., 10, 623-643, 2009.

Barrett, D. J. and Renzullo, L. J.: On the efficacy of combining thermal and microwave satellite data as observational constraints for root-zone soil moisture estimation, J. Hydrometeorol., 10, 11091127, 2009.

Best, M. J., Pryor, M., Clark, D. B., Rooney, G. G., Essery, R. L. H., Ménard, C. B., Edwards, J. M., Hendry, M. A., Porson, A., Gedney, N., Mercado, L. M., Sitch, S., Blyth, E., Boucher, O.,
Cox, P. M., Grimmond, C. S. B., and Harding, R. J.: The Joint UK Land Environment Simulator (JULES), model description Part 1: Energy and water fluxes, Geosci. Model Dev., 4, 677-699, doi:10.5194/gmd-4-677-2011, 2011.

BoM - Bureau of Meteorology: Australian Government, Water Data Online, available at: http://www.bom.gov.au/waterdata/, last access: 25 September 2015.

Brocca, L., Hasenauer, S., Lacava, T., Melone, F., Moramarco, T., Wagner, W., and Bittelli, M.: Soil moisture estimation through ASCAT and AMSR-E sensors: an intercomparison and validation study across Europe, Remote Sens. Environ., 115, 33903408, 2011.

Brocca, L., Moramarco, T., Melone, F., Wagner, W., Hasenauer, S., and Hahn, S.: Assimilation of surface and root-zone ASCAT soil moisture products into rainfall-runoff modelling, IEEE T. Geosci. Remote, 50, 2542-2555, 2012.

Burgers, G., van Leeuwen, P. J., and Evensen, G.: Analysis scheme in the ensemble Kalman filter, Mon. Weather Rev., 126, 17191724, 1998.

Cannon, A. J.: Quantile regression neural networks: implementation in $\mathrm{R}$ and application to precipitation downscaling, Comput. Geosci., 37, 1277-1284, 2011.

Chappell, A., Renzullo, L. J., Raupach, T. H., and Haylock, M.: Evaluating geostatistical methods of blending satellite and gauge data to estimate near real-time daily rainfall for Australia, J. Hydrol., 493, 105-114, 2013.

Chen, F., Crow, W. T., Starks, P. J., and Moriasi, D. N.: Improving hydrologic predictions of a catchment model via assimilation of surface soil moisture, Adv. Water Resour., 34, 526-536, 2011.

Clark, M. P., Rupp, D. E., Woods, R. A., Zheng, X., Ibbitt, R. P., Slater, A. G., and Uddstrom, M. J.: Hydrological data assimilation with the ensemble Kalman filter: use of streamflow observations to update states in a distributed hydrological model, Adv. Water Resour., 31, 1309-1324, 2008.

Crow, W. T., Bindlish, R., and Jackson, T. J.: The added value of spaceborne passive microwave soil moisture retrievals for forecasting rainfall-runoff partitioning, Geophys. Res. Lett., 32, L18401, doi:10.1029/2005GL023543, 2005.

Decharme, B., Alkama, R., Douville, H., Becker, M., and Cazenave, A.: Global evaluation of the ISBA-TRIP continental hydrological system, Part II: Uncertainties in river routing simulation related to flow velocity and groundwater storage, J. Hydrometeorol., 11, 601-617, 2010.

Decharme, B., Martin, E., and Faroux, S.: Reconciling soil thermal and hydrological lower boundary conditions in land surface models, J. Geophys. Res.-Atmos., 118, 7819-7834, 2013.

Dee, D. P., Uppala, S. M., Simmons, A. J., Berrisford, P., Poli, P., Kobayashi, S., and Vitart, F.: The ERA-Interim reanalysis: configuration and performance of the data assimilation system, Q. J. Roy. Meteorol. Soc., 137, 553-597, 2011.

De Jeu, R. A. M., Wagner, W., Holmes, T. R. H., Dolman, A. J., Van De Giesen, N. C., and Friesen, J.: Global soil moisture patterns observed by space borne microwave radiometers and scatterometers, Surv. Geophys., 29, 399-420, 2008.

d'Orgeval, T., Polcher, J., and de Rosnay, P.: Sensitivity of the West African hydrological cycle in ORCHIDEE to infiltration processes, Hydrol. Earth Syst. Sci., 12, 1387-1401, doi:10.5194/hess-12-1387-2008, 2008. 
Draper, C., Walker, J. P., Steinle, P. J., de Jeu, R. A., and Holmes, T. R.: An evaluation of AMSR-E derived soil moisture over Australia, Remote Sens. Environ., 113, 703-710, 2009.

Draper, C., Mahfouf, J.-F., Calvet, J.-C., Martin, E., and Wagner, W.: Assimilation of ASCAT near-surface soil moisture into the SIM hydrological model over France, Hydrol. Earth Syst. Sci., 15, 3829-3841, doi:10.5194/hess-15-3829-2011, 2011.

Ebtehaj, A. M. and Foufoula-Georgiou, E.: On variational downscaling, fusion, and assimilation of hydrometeorological states: A unified framework via regularization, Water Resour. Res., 49, 5944-5963, doi:10.1002/wrcr.20424, 2013.

Evensen, G.: Sequential data assimilation with a nonlinear quasigeostrophic model using Monte Carlo methods to forecast error statistics, J. Geophys. Res.-Oceans, 99, 10143-10162, 1994.

Evensen, G.: The ensemble Kalman filter: theoretical formulation and practical implementation, Ocean Dynam., 53, 343-367, 2003.

Gash, J. H. C.: An analytical model of rainfall interception by forests, Q. J. Roy. Meteorol. Soc., 105, 43-55, 1979.

Gevaert, A. I., Parinussa, R. M., Renzullo, L. J., van Dijk, A. I. J. M., and de Jeu, R. A. M.: Spatio-temporal evaluation of resolution enhancement for passive microwave soil moisture and vegetation optical depth, Int. J. Appl. Earth Obs., 45, 235-244, doi:10.1016/j.jag.2015.08.006, 2015.

Green, D., Petrovic, J., Moss, P., and Burrell, M.: Water resources and management overview: Murrumbidgee catchment, NSW Office of Water, Sydney, 2011.

Hijmans, R. J., Cameron, S. E., Parra, J. L., Jones, P. G., and Jarvis, A.: Very high resolution interpolated climate surfaces for global land areas, Int. J. Climatol., 25, 1965-1978, 2005.

Jones, D. A., Wang, W., and Fawcett, R.: High-quality spatial climate data-sets for Australia, Aust. Meteorol. Oceanogr. J., 58.4, 233-248, 2009.

Karssenberg, D., Schmitz, O., Salamon, P., de Jong, K., and Bierkens, M. F.: A software framework for construction of process-based stochastic spatio-temporal models and data assimilation, Environ. Model. Softw., 25, 489-502, 2010.

Kerr, Y. H., Waldteufel, P., Richaume, P., Wigneron, J. P., Ferrazzoli, P., Mahmoodi, A., and Delwart, S.: The SMOS soil moisture retrieval algorithm, IEEE T. Geosci. Remote, 50, 1384-1403, 2012.

Lanza, L. G., Schultz, G. A., and Barrett, E. C.: Remote sensing in hydrology: some downscaling and uncertainty issues, Phys. Chem. Earth, 22, 215-219, 1997.

Lee, H., Seo, D. J., and Koren, V.: Assimilation of streamflow and in situ soil moisture data into operational distributed hydrologic models: effects of uncertainties in the data and initial model soil moisture states, Adv. Water Resour., 34, 1597-1615, 2011.

Lee, H., Seo, D.-J., Liu, Y., Koren, V., McKee, P., and Corby, R.: Variational assimilation of streamflow into operational distributed hydrologic models: effect of spatiotemporal scale of adjustment, Hydrol. Earth Syst. Sci., 16, 2233-2251, doi:10.5194/hess-16-2233-2012, 2012.

Liang, X., Lettenmaier, D. P., Wood, E. F., and Burges, S. J.: A simple hydrologically based model of land surface water and energy fluxes for general circulation models, J. Geophys. Res., 99, 14415-14415, 1994.
Liang, X., Wood, E. F., and Lettenmaier, D. P.: Surface soil moisture parameterization of the VIC-2L model: evaluation and modification, Global Planet. Change, 13, 195-206, 1996.

Lievens, H., Tomer, S. K., Al Bitar, A., De Lannoy, G. J. M., Drusch, M., Dumedah, G., Hendricks Franssen, H.-J., Kerr, Y. H., Martens, B., Pan, M., Roundy, J. K., Vereecken, H., Walker, J. P., Wood, E. F., Verhoest, N. E. C. and Pauwels, V. R. N.: SMOS soil moisture assimilation for improved hydrologic simulation in the Murray Darling Basin, Australia, Remote Sens. Environ., 168, 146-162, 2015.

Lu, J., Sun, G., McNulty, S. G., and Amatya, D. M.: A comparison of six potential evapotranspiration methods for regional use in the southeastern United States, J. Am. Water Resour. As., 41, 621-633, 2005.

Massari, C., Brocca, L., Tarpanelli, A., and Moramarco, T.: Data assimilation of satellite soil moisture into rainfall-runoff modelling: a complex recipe?, Remote Sensing, 7, 11403-11433, 2015.

Merlin, O., Chehbouni, A., Boulet, G., and Kerr, Y.: Assimilation of disaggregated microwave soil moisture into a hydrologic model using coarse-scale meteorological data, J. Hydrometeorol., 7, 1308-1322, 2006.

Mitchell, T. D. and Jones, P. D.: An improved method of constructing a database of monthly climate observations and associated high-resolution grids, Int. J. Climatol., 25, 693-712, 2005.

Moradkhani, H.: Hydrologic remote sensing and land surface data assimilation, Sensors, 8, 2986-3004, 2008.

Naeimi, V., Scipal, K., Bartalis, Z., Hasenauer, S., and Wagner, W.: An improved soil moisture retrieval algorithm for ERS and METOP scatterometer observations, IEEE T. Geosci. Remote, 47, 1999-2013, 2009.

Nash, J. and Sutcliffe, J. V.: River flow forecasting through conceptual models part I - A discussion of principles, J. Hydrol., 10, 282-290, 1970.

New, M., Lister, D., Hulme, M., and Makin, I.: A high-resolution data set of surface climate over global land areas, Clim. Res., 21, 1-25, 2002.

Owe, M., De Jeu, R., and Holmes, T.: Multisensor historical climatology of satellite-derived global land surface moisture, J. Geophys. Res.-Earth, 113, F01002, doi:10.1029/2007JF000769, 2008.

Peischl, S., Walker, J. P., Rüdiger, C., Ye, N., Kerr, Y. H., Kim, E., Bandara, R., and Allahmoradi, M.: The AACES field experiments: SMOS calibration and validation across the Murrumbidgee River catchment, Hydrol. Earth Syst. Sci., 16, 16971708, doi:10.5194/hess-16-1697-2012, 2012.

Rakovec, O., Weerts, A. H., Hazenberg, P., Torfs, P. J. J. F., and Uijlenhoet, R.: State updating of a distributed hydrological model with Ensemble Kalman Filtering: effects of updating frequency and observation network density on forecast accuracy, Hydrol. Earth Syst. Sci., 16, 3435-3449, doi:10.5194/hess-163435-2012, 2012.

Reichle, R. H. and Koster, R. D.: Bias reduction in short records of satellite soil moisture, Geophys. Res. Lett., 31, L19501, doi:10.1029/2004GL020938, 2004.

Reichle, R. H., De Lannoy, G. J., Forman, B. A., Draper, C. S., and Liu, Q.: Connecting satellite observations with water cycle variables through land data assimilation: examples using the NASA 
GEOS-5 LDA S, in: The Earth's Hydrological Cycle, Springer, the Netherlands, 577-606, 2014.

Renzullo, L. J., van Dijk, A. I. J. M., Perraud, J. M., Collins, D., Henderson, B., Jin, H., and McJannet, D. L.: Continental satellite soil moisture data assimilation improves root-zone moisture analysis for water resources assessment, J. Hydrol., 519, $2747-$ $2762,2014$.

Rienecker, M. M., Suarez, M. J., Gelaro, R., Todling, R., Bacmeister, J., Liu, E., and Woollen, J.: MERRA: NASA's modern-era retrospective analysis for research and applications, J. Climate, 24, 3624-3648, 2011.

Sahoo, A. K., De Lannoy, G. J., Reichle, R. H., and Houser, P. R.: Assimilation and downscaling of satellite observed soil moisture over the Little River Experimental Watershed in Georgia, USA, Adv. Water Resour., 52, 19-33, 2013.

Schellekens, J.: OpenStreams wflow documentation release 1.0RC1, Deltares, available at: http://wflow.readthedocs.org/en/ latest/ (last access: 25 September 2015), 2014.

Smith, A. B., Walker, J. P., Western, A. W., Young, R. I., Ellett, K. M., Pipunic, R. C., Grayson, R. B., Siriwardena, L., Chiew, F. H. S., and Richter, H.: The Murrumbidgee soil moisture monitoring network data set, Water Resour. Res., 48, W07701, doi:10.1029/2012WR011976, 2012.

Su, C. H., Ryu, D., Young, R. I., Western, A. W., and Wagner, W.: Inter-comparison of microwave satellite soil moisture retrievals over the Murrumbidgee Basin, southeast Australia, Remote Sens. Environ., 134, 1-11, 2013.

Sun, C., Walker, J. P., and Houser, P. R.: A methodology for snow data assimilation in a land surface model, J. Geophys. Res.Atmos., 109, D08108, doi:10.1029/2003JD003765, 2004.

Sutanudjaja, E. H., van Beek, L. P. H., de Jong, S. M., van Geer, F. C., and Bierkens, M. F. P.: Large-scale groundwater modeling using global datasets: a test case for the Rhine-Meuse basin, Hydrol. Earth Syst. Sci., 15, 2913-2935, doi:10.5194/hess-152913-2011, 2011.

Tangdamrongsub, N., Steele-Dunne, S. C., Gunter, B. C., Ditmar, P. G., and Weerts, A. H.: Data assimilation of GRACE terrestrial water storage estimates into a regional hydrological model of the Rhine River basin, Hydrol. Earth Syst. Sci., 19, 2079-2100, doi:10.5194/hess-19-2079-2015, 2015.

Van Beek, L. P. H. and Bierkens, M. F. P.: The Global Hydrological Model PCR-GLOBWB: Conceptualization, Parameterization and Verification, Tech. Rep., Department of Physical Geography, Utrecht University, Utrecht, the Netherlands, available at: http: //vanbeek.geo.uu.nl/suppinfo/vanbeekbierkens2009.pdf (last access: 28 February 2011), 2009.

Van Beek, L. P. H., Wada, Y., and Bierkens, M. F. P.: Global monthly water stress: I. Water balance and water availability, Water Resour. Res., 47, W07517, doi:10.1029/2010WR009791, 2011.

van Dijk, A. I. J. M.: The Australian water resources assessment system, Version 0.5, available at: http: //www.clw.csiro.au/publications/waterforahealthycountry/ 2010/wfhc-awras-evaluation-against-observations.pdf (last access: 8 December 2015), 2010. van Dijk, A. I. J. M. and Renzullo, L. J.: Water resource monitoring systems and the role of satellite observations, Hydrol. Earth Syst. Sci., 15, 39-55, doi:10.5194/hess-15-39-2011, 2011.

van Dijk, A. I. J. M., Renzullo, L. J., Wada, Y., and Tregoning, P.: A global water cycle reanalysis (2003-2012) merging satellite gravimetry and altimetry observations with a hydrological multi-model ensemble, Hydrol. Earth Syst. Sci., 18, 2955-2973, doi:10.5194/hess-18-2955-2014, 2014.

Vertessy, R. A. and Elsenbeer, H.: Distributed modeling of storm flow generation in an Amazonian rain forest catchment: effects of model parameterization, Water Resour. Res., 35, 2173-2187, 1999.

Vörösmarty, C. J., Fekete, B. M., Meybeck, M., and Lammers, R.: A simulated topological network representing the global system of rivers at $30 \mathrm{~min}$ spatial resolution (STN-30), Global Biogeochem. Cy., 14, 599-621, 2000.

Vrugt, J. A., Gupta, H. V., Nualláin, B., and Bouten, W.: Real-time data assimilation for operational ensemble streamflow forecasting, J. Hydrometeorol., 7, 548-565, 2006.

Wanders, N., Karssenberg, D., Bierkens, M., Parinussa, R., de Jeu, R., van Dam, J., and de Jong, S.: Observation uncertainty of satellite soil moisture products determined with physically-based modeling, Remote Sens. Environ., 127, 341356, doi:10.1016/j.rse.2012.09.004, 2012.

Wanders, N., Karssenberg, D., de Roo, A., de Jong, S. M., and Bierkens, M. F. P.: The suitability of remotely sensed soil moisture for improving operational flood forecasting, Hydrol. Earth Syst. Sci., 18, 2343-2357, doi:10.5194/hess-18-23432014, 2014a.

Wanders, N., Bierkens, M. F., de Jong, S. M., de Roo, A., and Karssenberg, D.: The benefits of using remotely sensed soil moisture in parameter identification of large-scale hydrological models, Water Resour. Res., 50, 6874-6891, doi:10.1002/2013WR014639, 2014b.

Wanders, N., Bierkens, M., Sutanudjaja, E., and van Beek, R.: The PCR-GLOBWB global hydrological reanalysis product, in: EGU General Assembly Conference Abstracts, Vol. 16, p. 5369, 2014c.

Weedon, G. P., Balsamo, G., Bellouin, N., Gomes, S., Best, M. J., and Viterbo, P.: The WFDEI meteorological forcing data set: WATCH forcing data methodology applied to ERA-Interim reanalysis data, Water Resour. Res., 50, 7505-7514, 2014.

Wesseling, C. G., Karssenberg, D. J., Burrough, P. A., and Deursen, W.: Integrating dynamic environmental models in GIS: the development of a dynamic modelling language, Trans. GIS, 1, 40-48, 1996.

$\mathrm{Wu}, \mathrm{H}$. and Li, Z.-L.: Scale issues in remote sensing: a review on analysis, processing and modeling, Sensors, 9, 1768-1793, 2009.

Zaitchik, B. F., Rodell, M., and Reichle, R. H.: Assimilation of GRACE terrestrial water storage data into a land surface model: results for the Mississippi River basin, J. Hydrometeorol., 9, 535-548, 2008. 